\title{
Existence, Identity and Survive Strategy Kethoprak Tobong Kelana Bhakti Budaya
}

\section{Inggit Sitowati}

Ethnomusicology Department, Indonesia Institute of the Arts Surakarta email: inggitsitowati@gmail.com

\begin{abstract}
Kethoprak Tobong Kelana Bhakti Budaya is one of Ketoprak tobong that still exist and survive from the onslaught of modern entertainment. Ketoprak tobong is a traditional Javanese theatrical art which performs and lives by moving from one place to another within a period of time. They maintain their existence because of their deep love for the Ketoprak world. In addition they have a sense of responsibility to preserve the nation's cultural heritage by maintaining their tobong group. For them the Ketoprak world and tobong is their identity. The members of this group were born and grew up from the Ketoprak's family and environment. The existence and identity of this group is formed from habitus, capital and field. For survive strategy, they apply the principles of kinship, flexibly apply the rules, looking for donors, and promotes the group through a variety of cultural events. To make ends meet they have other jobs, including craft, making costumes, makeup, and a singer in a wedding.
\end{abstract}

Keywords: Ketoprak tobong, existence, identity, and survival strategies.

\section{INTRODUCTION}

One of the problems faced by traditional arts in Indonesia is losing fans and viewers. From day to day, the amount of fans and spectators of traditional arts wanes. This condition is caused by the onslaught of modern entertainment in the community. Industrial pop makes people prefer modern entertainment.That problem is also faced by traditional Ketoprak artists in Indonesia. Many Ketoprak performance is not saleable and only viewed by handful of people. One by one the Ketoprak group's dies. Many Ketoprak performers lost their jobs therefore they switch professions. Traditional Ketoprak performances become less and less today.

One of Ketoprak group that survive is Ketoprak Tobong Kelana Bhakti Budaya. Ketoprak tobong is a Ketoprak group who lives and does their performances discursively. They built a stage and a place to stay behind the stage in a designated area within a certain time, then move to another area. The group currently lives in the village of Bayen, Purwomartani, Kalasan, Yogyakarta. This group holds regular performances twice a week every Wednesday and Saturday night.

Ketoprak Tobong Kelana Bhakti Budaya also experiences similar problems. Despite having major problems in the decreased fans and spectators, the groups maintain their existence and run their performances routinely. It can be said that the income they earn from routine performances in tobong cannot meet the needs of everyday life. But they persisted and perform a variety of ways to make ends meet. They make efforts so 
that they can exist and survive. This paper examines how Kethoprak Tobong Kelana Bhakti Budaya retains their existence to this day. Why do they maintain the group and assume Ketoprak tobong as their identity. This paper also discussed about their effort and survival strategies.

\section{MATERIALS AND METHODS}

The research method used is a qualitative method with a case study approach. This method seeks to explain a decision or set of decisions about why the decision was taken, how the implementation is, and how are the results (Yin, 1989: 23). The study was conducted by means of observation by watching a variety of performances done by Kethoprak Tobong Kelana Bhakti Budaya and deeply understanding it. More detailed data are obtained from in-depth interviews with the owners, administrators and members of this group. All the data obtained from the field are then analyzed, reduced by summarizing, and focused on the important things according to the theme, categorized, and lastly be drawn conclusions that are related to the interpretation of the researcher.

\section{DISCUSSION}

\section{A. Description of Ketoprak and Ketoprak Tobong}

Ketoprak is a theatrical folk art originated from Java. Ketoprak Performance is a drama with the accompaniment of gamelan music played with a duration of approximately two to four hours. Dialogue in Ketoprak uses Java language. In Ketoprak there are also dance performances and tembang or Java songs. The players use appropriate costumes and makeup according to their story characters. (Lisbijanto, 2013). Ketoprak was created by RM. Wreksoniningrat, a dance and puppet artists from Solo. Ketoprak players were initially all male. As the times and the demands of the story which are increasingly varied, Ketoprak then also played by women. At the beginning of its emergence, Ketoprak used more dances and used little dialogue. Along the times, there are more dialogue between players, but still retained its elements of dance.

Stories in Ketoprak called lakon, is the story of the fourth to the eighteenth century kings, folk tales, legends, myths, and new story created by the director. Ketoprak always displays a serious scene, war and humor. The story in each Ketoprak performances is divided into several major scenes. The opening scene is in the form of depiction of palace atmosphere. The next scene is in the form of atmosphere outside the palace. Then is the meeting scene between the villain and the hero character followed by war. The final scene is in the form of good character win against villain character. The plot of Ketoprak story is called pakem which done but not written in any Ketoprak performances. The story or lakon in Ketoprak although diverse and different but broadly describes the good always conquers evil.

Accompaniment of gamelan music in each Ketoprak performance has an important role. Gamelan illustrates music which delivers an atmosphere appropriate to the storyline and scenes. Tembang or Javanese traditional song characterize Ketoprak, 
even its dialogue is sung. Waranggana or sinden (Javanese/gamelan singer) sing the songs which are adapted to the story that has been directed by the director. In every show there are two to four Ketoprak sinden. Sometimes sinden sing songs requested by the audience. Ketoprak performers should be able to dance and nembang (Javanese traditional singing). They are required to converse well and fully comprehend their character. Ketoprak performers generally is a member of a Ketoprak group that has long played Ketoprak and has the ability to play a variety of characters. The performers practice regularly in order to have the expertise. Beginners are usually given small roles or just appear on one of the scenes.

Stage used in Ketoprak performance is given decoration and lighting supporters. The stage decoration is in accordance with the settings of each scene. The screen is also an important part of Ketoprak performance. The screen is an image of the location of the scene in the form of palace, forest, park, or square. Ketoprak as traditional arts not only serve as an entertainment for the community. Ketoprak has other functions in the form of a ritual function, namely as a means to perform a ritual ceremony as the ritual requirement. The second function is education, ie the transformation of cultural values, morals and philosophy of life for the audience. The last function is as a social critic, satirical social conditions of society through characters and dialogues played.

Ketoprak has developed according to the demands of times. The story (lakon) is not always applying pakem rigidly, but there is innovation according to the audience interest. In the 1980-1990 develops Ketoprak plesetan which have story, dialogue and characters more freely with non-rigid pakem. It story has kingdom background but more actual with free style full of humor language with varying figures. In the 1995's emerge Ketoprak humor which is highlighting humor functions and use language more freely even using Indonesian.

Ketoprak Tobong or Ketoprak Tonil is a Ketoprak which is performed from one place to another within a certain period of time. Not only the players moved, but they bring also all the stage equipment, like stage, costumes, stage decorations, chairs, gamelan, sound system, diesel, and the residence of the performers called tobong. Ketoprak tobong is a Ketoprak nomadic group such as the group of gypsies. (Yowono, 2012). Tobong is the abode of the Ketoprak performers with all the stage equipment in the form of gamelan, costumes, screen, decoration, sound system, lights, and so forth. Tobong is placed somewhere within a certain time and then disassembled to be moved to next Ketoprak show place. Tobong is not permanent and ready to be disassembled at any time. Ketoprak tobong members follow wherever tobong stopped and settled in an area. The performers live by following the tobong movement and the Ketoprak performances. They bring their Families and children to where the Ketoprak performs.

\section{B. History and Description of Kethoprak Tobong Kelana Bhakti Budaya}

Kethoprak Tobong Kelana Bhakti Budaya was originally named Kethoprak Sri Budaya under the leadership of Sri and lived in Kediri. The group then changed its name to Candra Kirana with Bagong and Lilik as its leaders. In 1997, Candra Kirana group had 
difficulty. The owner asked for the help of Reverend Dwi Tartiyasa to manage together and find donors so that this group could still perform. ${ }^{1}$

Reverend Dwi at that time served in Baptist Church Setia Bakti Kediri. He is a Ketoprak fan and always watch Ketoprak Candra Kirana show. Because he oftenly watch their performance he has closeness to the owner and members of this tobong group. Therefore, when the tobong group had trouble, their leader ask Reverend Dwi to manage it together. He eventually become the leader. But with three leaders its management became unfocused. Then Bagong asked Reverend Dwi to buy Ketoprak tobong. Reverend Dwi bought the Ketoprak for six and a half million dollars in 2000. The group's name was later changed to Kethoprak Tobong Kelana Bhakti Budaya. Bhakti is taken from the name of Reverend Dwi church. Name Kelana was added by him because this group is always wandering around from place to place. In addition it has a philosophical meaning that all life on earth is ultimately returned to the Creator. While the name Budaya is added as Ketoprak is a part of Indonesian culture especially Java. Name Kethoprak Tobong Kelana Bhakti Budaya was inaugurated on July 23rd, 2000.

Under the leadership of Reverend Dwi, the group has moved to many areas. In 2003 he moved to work in Jakarta. From Kediri this group moved to Purwodadi for three months and are managed remotely by him with the help of his brother. The group then moved to Kediri again. In 2005 he moved to Yogyakarta. This group still survived in Kediri. In 2006 after an earthquake, the group moved to Yogyakarta.In Yogyakarta, this group has moved to various places. Village or hamlet that once housed in the Special Province of Yogyakarta, among others are; in Cokrowijayan - Sleman, Cebongan - Sleman, Sidomulyo - Sleman, Kembaran - Bantul, Bangunjiwo - Bantul, Njodog Bantul. They inhabit the villages or hamlets within approximately three months to one year at each place. The reasons they moved to various places, among other things because of the condition of the audience which is few, problem in residence permit, or problems with the residents and village officials.

During his stay in village Njodog, Bantul, this group experienced a financial crisis. They need financial help to manage tobong. Risang, Reverend Dwi's son, then made a performance with the title "Pamit Mati" which was held in Alun-alun Selatan on May 31, 2010 The purpose of this performance was to convey to the indigenous stakeholders of Yogyakarta that the only surviving tobong group in Yogyakarta is nearly dead, and they requested the attention of governments and society. Unfortunately, despite of the performance and went to several government agencies, the government did not provide any response and assistance.

The group then moved again to the village Bayen, Kalasan, Sleman. They occupy an area of rice fields in the hamlet. They can stay in village Bayen by the help of Risang former boss (Reverend Dwi's son) called Ratna. Ratna incidentally watched "Pamit Mati". Reverend Dwi asked Ratna so that his tobong group can occupy an area that is still in a pretty good condition. Ratna provide three alternative places; Magelang,

1 This chapter was gained from interviewing tobong owner reverend Dwi Tartiyasa, September $3^{\text {rd }}$, 2014. 
Pakem, and Kalasan. Reverend Dwi choose Kalasan. Ratna permitted this group to occupy the land. This group has lived and performed in the area, since 2010 until now. The conditions of spectators at the venue though few but they always come to watch their performance. The audience mostly came from other areas, not only the residents around the village.

During their moving in these areas the members in this group is waning. One by one they left tobong and returned to their hometown. The reason is due to the fewer number of spectators and fewer salaries. The members of this tobong which is originally about thirty people, is now reduced to eight people. This group performs in that place every Wednesday and Saturday night starting at nine o'clock. When do their performance they are assisted by Ketoprak performers from other groups, especially the Ketoprak performers from villages. Additional performers come to play when the group performs in their tobong or elsewhere. The Ticket price of a routine show is Rp. 5,000. Performers and other crews salary is around Rp. 5,000 to Rp. 10,000 for each performance, according to their roles and duties.

\section{The Existency and Identity of Kethoprak Tobong Kelana Bhakti Budaya}

Kethoprak Tobong Kelana Bhakti Budaya despite having difficulties in financial terms, are able to maintain their existence. Although the condition is not as good as during Ketoprak golden era in the past, this group is able to survive. They did not disperse but tries hard so tobong can still exist. When the income is calculated, it does not meet the needs of everyday life for its members. The main factor that makes this group stay afloat amid incessant pop entertainment is great love of Ketoprak. The owner and all the members of this group have great love in Ketoprak world. They remain faithful to follow this tobong. Despite their financial problems, they remain faithful to be part of this family.

The main motivation Reverend Dwi bought this tobong group; first is of spirituality. He purchased and became the leader of the group is to implement love in real form. Love and affection are distributed in the form of helping and nurturing the members so that they can continue to exist and maintain their life in Ketoprak tobong. ${ }^{2}$

Another underlying motivation Reverend Dwi bought this group is as a contribution to the culture in a way to preserve it. Ketoprak tobong is a form of Indonesian culture. So he wants to maintain this tobong group so as not to be lost. He has confidence that the current Ketoprak tobong which is is rivaled by electronic media such as DVD and internet(youtube), at some point will become public interest once again. He believes that one day will return to the deep-rooted cultural tradition.

Ketoprak Tobong members whose numbers were down to eight people are also able to survive because of their love toward Ketoprak world. Because of their love for Ketoprak world, the members of this tobong survive and become a form of efforts to preserve the nation's cultural traditions. They do not want Ketoprak to lost against

2 Interview with Reverend Dwi Tartiyasa, September $3^{\text {rd }}, 2014$ 
modern entertainments. They remained so Ketoprak can be performed and viewed by society. ${ }^{3}$

Ketoprak world has become their lives. Therefore they cannot leave the world of Ketoprak. For members of this tobong, Ketoprak will not be left until the end of their lives. The owner and members of this group already considered Ketoprak as their identity and cannot be eliminated.According to Giddens (Barker, 2000: 175-176), self-identity is formed on the ability to maintain self-concept that forms a continuous feeling. Identity forms some questions about what to do, how to act, and wants to become. From Giddens's concept it can be concluded that the identity of the owner and tobong group members eventually form an action about what they should do, how they act, and want to be in tobong group.Based on Giddens concept, the identity of the owner and members of this group eventually formed a collectivity. So it forms social identity where there are an associations of normative rights, obligations and sanctions on certain collectivity, which forms the role. The owner and the group members become a social identity in which they work together, run the rights and obligations collectively, respect and help each other, to performs well and maintain the integrity of the group. They also perform its role according to ability and position, namely: leader manages the group; players perform well, the director set up the performance, and the equipper set the decorations and setting.

\section{Habitus, Capital and Field That Forms Existence and Identity of Ketho- prak Tobong Kelana Bhakti Budaya}

Kethoprak Tobong Kelana Bhakti Budaya members even spent half of their life in tobong. They were from Ketoprak owners or performers family background. Every day they are in Ketoprak environment. This is what fosters a love for the Ketoprak world and tobong.

The group members have been like a big family. Even among those who are married and have a family with fellow members. Their children also live in tobong. Their family background has shaped the interests and tastes of the members since they were little. ${ }^{4}$

This social phenomenon is consistent with the concept of Bourdieu (1994) on habitus. Habitus is a process of internalization through a long history, which is resulted in mindset, perception, judgment, taste, expression, appreciation, ideals, ways of thinking, personality, ethos, and act in accordance with the environmental or social class. Skill results which become practical action that is not necessarily realized then become the move source in a social environment. (Haryatmoko, 2003, 11). So interest, taste, appreciation, aspiration to the mindset of the performers and its members are formed from habitus which is obtained through internalization since childhood in a family environment full of Ketoprak actors.

The tobong members since childhood have seen their parents and families work in Ketoprak environment. They are trained from childhood to master wide range of 
skills that support Ketoprak; nembang (Javanese traditional singing), dancing, playing the gamelan, makeup and making costumes or props. Each player is required to have a variety of skills in Ketoprak because in addition to performs they also dancing, acting, and nembang. After mastering the skills of dancing and nembang, they began to appear in Ketroprak performances. They get a small role first. They must learn from small roles and gain knowledge from senior players on the stage. For male, they are not deployed initially as a performer, but they begin by helping the stage decoration. After that the male players get a small role in the performance. From a small role then increased in portion according to their role playing skills. Once mastered and have many skills and experience, they finally gained an important role or a major role.

Reverend Dwi's love of Ketoprak is also transmitted to his family. Since before he owns Ketoprak tobong, he always watch the show in his area. Because of the tasks and activities of Reverend Dwi as the owner of Ketoprak tobong, his children eventually fond and love Ketoprak. His son, Risang, actively participates in managing this tobong group and became the initiator of creative ideas for tobong performance.

Habitus then leads to Bourdieu's concept of capital. According to Bourdie resource ownership determines the positions of a person in the society. Capital accumulated through investment, can be inherited, and provide benefits in accordance with the occasion. Bourdieu capital divide into four. First is the economic capital or the economic ownership. Second, cultural capital, is the knowledge gained, including educational, cultural codes, ways of speaking, writing skills, carriage way, how to get along, manners, and so forth. Third is social capital, the network of connections and relationships. Fourth is symbolic capital, the honor and social prestige (Bourdieu, 1994). The position of people in social classes, depends on the magnitude of the amount of ownership and capital structure. Based on Bourdieu's concept of capital, the cultural capital that the members have are the Ketoprak skills and expertise that they have been acquired since they are small in the family and from environment. Social capital of the group members is a relationship and connection with Ketoprak figures available around the environment. Symbolic capital of the members of this group is a privilege identity as Ketoprak performers. These three capital provide economic capital in the form of fees and income from Ketoprak although only slightly.

The concept of habitus and capital refers to the concept of the field. Field according to Bourdieu is a network of relations between objective positions in them (Jenkins, 2004: 124). Field is a social environment that is more or less homogeneous, and in it there is a struggle over resources or access. The agents in an arena must master the codes and rules. People will not understand the strategy of the agents they does not related to the field, where there are positions or their position in it. Occupants of a position in the field can be either an individual or institution. Habitus and capital owned by the members maked them aware about their field in tobong. Because of grows up in tobong neighborhood, they already understand and execute the codes, rules, and strategies in the Ketoprak tobong field. They know the way, strategies and rules in order to get important roles. So they know the tricks and strategies in order to survive 
and to get promotion. Habitus, capital and field owned by the owner and members of this group form their own identity. So they have the confidence and resolve to maintain the existence of the group.

\section{E. Strategies to Survive Kethoprak Tobong Kelana Bhakti Budaya}

Kethoprak Tobong Kelana Bhakti Budaya has done various efforts to survive and exist against the onslaught of pop entertainment. Both of the owner and members tries to stay afloat as Ketoprak tobong. Income from regular performances in two times a week can not meet the operating costs. Income derived from the audience during every show is also do not provide sufficient salary for members and other additional players. So both the owner and tobong members should do a lot of efforts to survive.

The owner and his son have made various efforts to obtain help from government and private parties. They have come and tried to ask for help so that government agencies and private groups willing to provide assistance. They have creating and send a proposal for assistance to various agencies. They also tried to embrace the patrons of culture, community, and cultural institutions. ${ }^{5}$

Unfortunatelly the government agencies pay no attention at all to this group. The owner's son who now becomes the successor once held a show as a quest for attention and assistance from the government. The show was named "Pamit Mati" which was held in South Square on May 31, 2010. "Pamit Mati" was held with the intention to convey to the indigenous stakeholders Sri Sultan HB X if they are the only tobong kethoprak that still exist in Yogyakarta. As the only remaining Ketoprak tobong in Yogyakarta is dying. They expect the local authorities will help. As a group of Ketoprak tobong they do not want to die. Unfortunately, although has been invited, Sri Sultan, Governor of Yogyakarta, do not come to the show. Local authorities do not give any attention to this group.

Assistance to this group come from non-government parties. One of them is the Indonesian British Council's cultural institutions. British Council assists in marketing and publicity. These institutions provide assistance in the form of marketing campaigns and photography. They hold a photography exhibition to promote this tobong group. It aims to bring a new audience to Ketoprak tobong. In addition, Art Council England a foreign cultural institution also provide financial support for the physical construction of tobong. Assistance from both the foreign cultural institutions came from Risang collaboration with a British artist, Helen Marshall. They made an art project that was funded by the British Council. The project was named "Project Tobong", which was first held in ICAN (Indonesian Contemporary Art Network), in Yogyakarta, in 2012. The British Council supported that project because they are keen for the work to reach wider audiences, both, so that people might experience the photographs but also to increase awareness and interest in the Ketoprak tobong among wider public. With that programme they hope that people will have the opportunity to see a window onto the unique of Ketoprak tobong community and the 
way of their life. Through that programme they aim to share British and Indonesian artistic practice, society and culture with people around the world. ${ }^{6}$

This group also received cooperation from Via-Via Cafe. In the form of finding foreign guests to watch Ketoprak tobong show. Via-Via Cafe makes booklets and tour packages promotion. The tour package is in the form of a tour to see Ketoprak tobong living area and life in tobong. The goal of this package are foreign tourists. Tobong owner also seeks the help of sponsors and donors. Currently there are several donors who provide financial assistance. Donors come from relatives, church relations, friends and others. The donors also provide support so that this group still exist and persist. They also received an invitation to perform in cultural event. One of them is in Yogyakarta Arts Festival 2014 on September 5, 2014 at Plaza Ngasem. The title of the play is "Pepet ing 1965", the core of the story is the story of a crime. Performance at arts and cultural events is a form of business promotion and introduction to the community. So the people would be interested and come to their regular performances at tobong. Survival strategies that they employ in everyday life in tobong one of them is to apply the principle made by the leader "Nyambung urip bareng". The meaning of these principles is to share and kinship. So the members of this tobong family live in harmony and help each other.

The rules is not as tight as on Ketoprak heyday. They do not apply the strict rules in selecting players. In the past, to be an important role player, they need to go through a rigorous selection and have a high level of ability. But now the group is more flexible. They accept other Ketoprak players to help and join their performances. They also accept other people who come to learn. One of them is by receiving a theater group to perform at their tobong as a form of learning. To earn additional income in order to cover the operating costs and additional income for the members, then the owner additionally promoting and accepting any performances outside tobong. As a reverend, he hold Ketoprak performances in church celebration. Ketoprak performance held in church on the occasion of Christmas, Easter, or other church celebrations. The story is taken from the Holy Bibles. They then make adjustments and create a new script. Although the members of this group is not a Christian, but they work in total.

The group also received a request performance at events agencies. They are also performing in another village or town on demand. The story is customized to the theme of the event. In general, they are looking for a story or create a new story that aims for social criticism or as learning media. Income from spectator and ticket at regular performances are not able to provide sufficient salary for the players. The director, cast, and crew involved only received an honorarium of about Rp. 5,000 to Rp. 10,000 on each show. To meet the needs of everyday life, tobong members have other jobs. Other work owned by the members are crafts, makeup artist, singer or sinden at weddings or other events, costume stylist in Ramayana Ballet Prambanan, selling food and beverages, coaching gamelan, and more. The members also accepted

$6 \quad$ Email from Evonne Mackenzie, Director Arts British Council Indonesia, October $4^{\text {th }} 2014$ 
the offer to performs at another groups. Those other works eventually became the vigil to meet the needs of their lives.

\section{RESULTS}

Kethoprak Tobong Kelana Bhakti Budaya until now survived and still exists in the midst of modernization. They have undergone name changes and owners several times. This group also experienced a lot of displacement to various areas of several provinces in Java. Although it has experienced a financial crisis but the owner and the members tries to maintain the group's existency. Deep love for Ketoprak world and tobong become the main factor to survive. They still fights for the group's existence to preserve the national culture in the form of Ketoprak. A love for Ketoprak and tobong ultimately shapes the identity of the owner and of group members. For them Ketoprak tobong is their identity and they will not leave it. Their love for Ketoprak world and tobong is formed from habitus, capital and field. Habitus, capital, and field of Ketoprak tobong arise because the members were born and grew up on the family and the environment of Ketoprak tobong.

\section{CONCLUSION}

Survival strategy of this group is done in various ways. They attempted to ask the government for help but they do not get their attention. They also tried to embrace the patrons of culture, community, and cultural institutions. Help came from foreign cultural institutions and private sector which help in marketing, promotion and funding. Donors also come from family or other relatives. The principle of kinship and mutual aid is applied in the group. Selection and rules for performers are also not strictly applied. Meanwhile, to meet the needs of everyday life, the members have other side jobs that support their finances. Unfortunately, the government is not paying attention and assistance to this group. Traditional arts groups like this should be supported and assisted by both government and society at large in order to not become extinct.

\section{REFERENCES}

Barker, Chris. (2000), Cultural Studies, Theory and Practice, London: Sage Publications. Bourdieu, Pierre. (1994), Distinction: A Social Critique of the Judgement of Taste, London: Routledge.

Haryatmoko. (2003), “Menyingkap kepalsuan budaya penguasa; landasan teoritis gerakan sosial menurut Pierre Bourdieu", dalam Basis, No 11-12, tahun ke-52, 2003, Yogyakarta: Yayasan BP Basis.

Jenkins, Richard. (2004), Membaca Pikiran Pierre Bourdieu, terj. Nurhadi, Yogyakarta: Kreasi Wacana.

Lisbijanto, Herry.( 2013), Ketoprak, Yogyakarta: Graha Ilmu.

Susanto, Budi, Dr., SJ. (1997), Ketoprak: The Politics of the Past in the Present-Day Java, Yogyakarta: Kanisius.

Yin, Robert K. (1989), Case Study Research, Design and Methods, California, USA: Sage Publication Inc., Newbury Park. 


\section{ONLINE RESOURCES}

Yuwono, Risang. (2012), http://kethopraktobong.blogspot.com/2012/08/apa-itukethoprak-tobong.html, accessed on July $26^{\text {th }} 2014$.

\section{INTERVIEWS:}

1. Reverend Dwi Tirtayasa, the owner of Ketoprak Tobong, September $3^{\text {rd }}, 2014$

2. Risang Yuwono, the son of the owner of Ketoprak Tobong who becomes the member and the successor, July $17^{\text {th }} 2014$

3. Rini, member of Ketoprak Tobong, September $9^{\text {th }} 2014$

4. Wiwin, members of Ketoprak Tobong, September $9^{\text {th }} 2014$

5. Mak Kamek, member of Ketoprak Tobong, July $17^{\text {th }} 2014$

6. Evonne Mackenzie, Director Arts British Council Indonesia, by email, October $4^{\text {th }}$ 2014

\section{Enclouser (Pictures of Kethoprak Tobong Kelana Bhakti Budaya)}

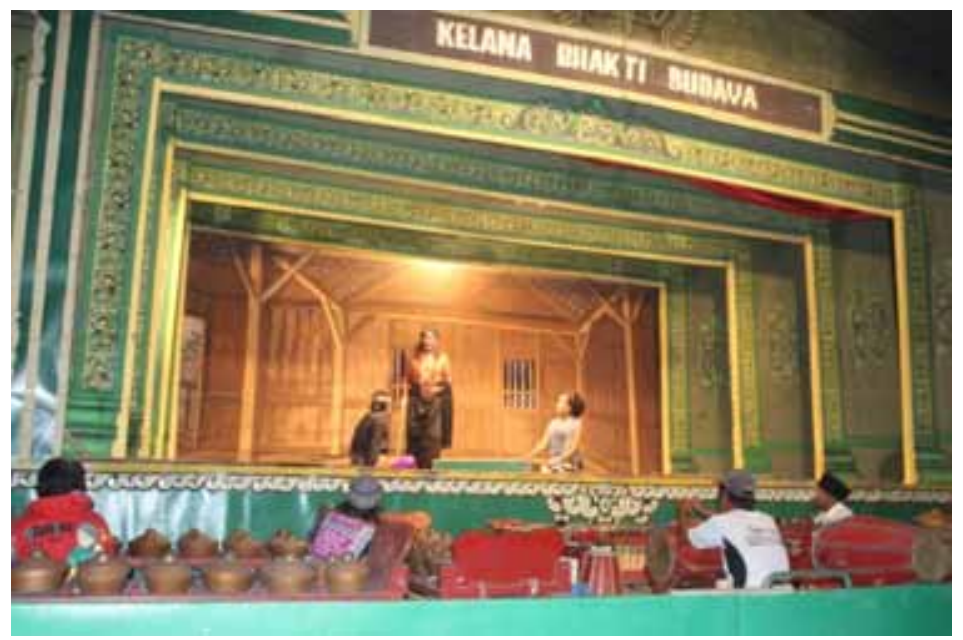

The Performance

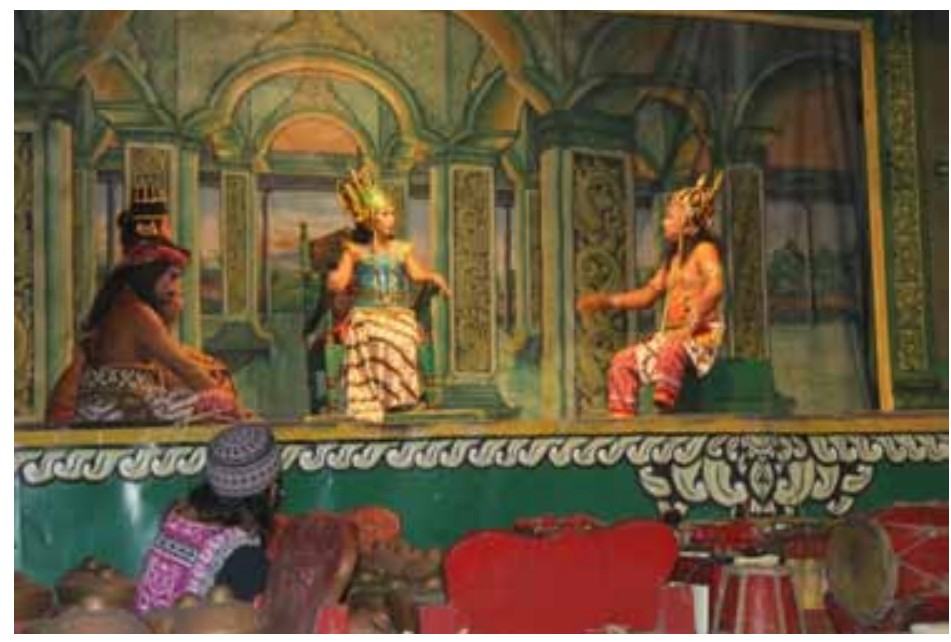

The Performance 


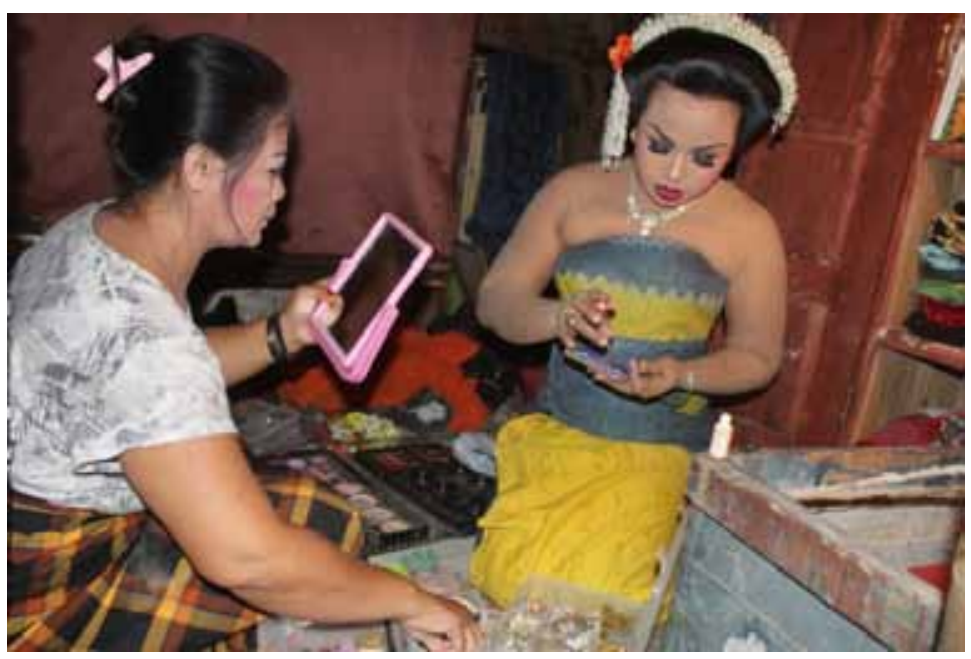

Preparation

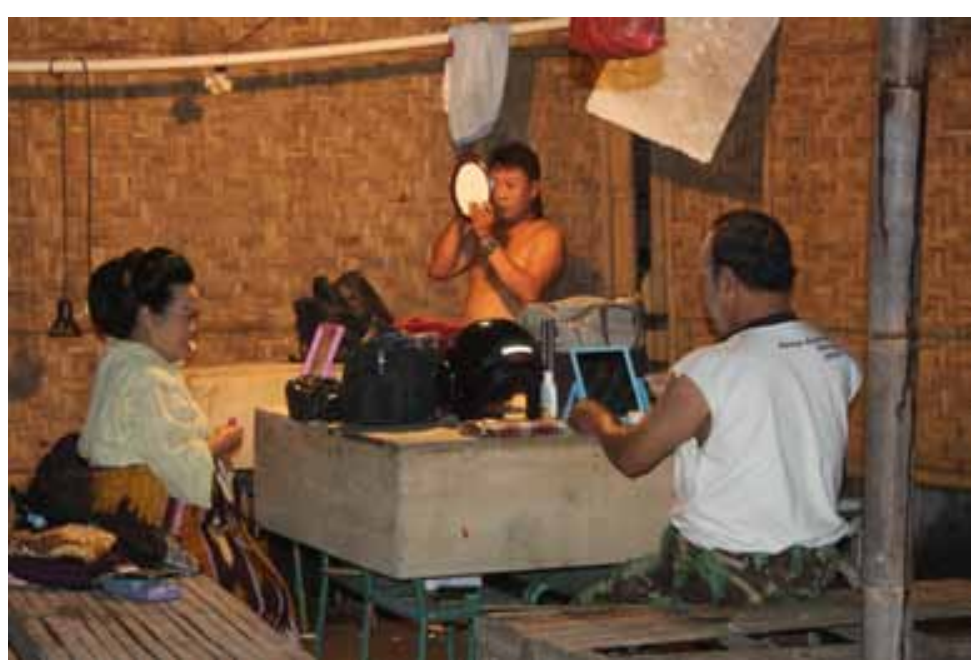

Preparation

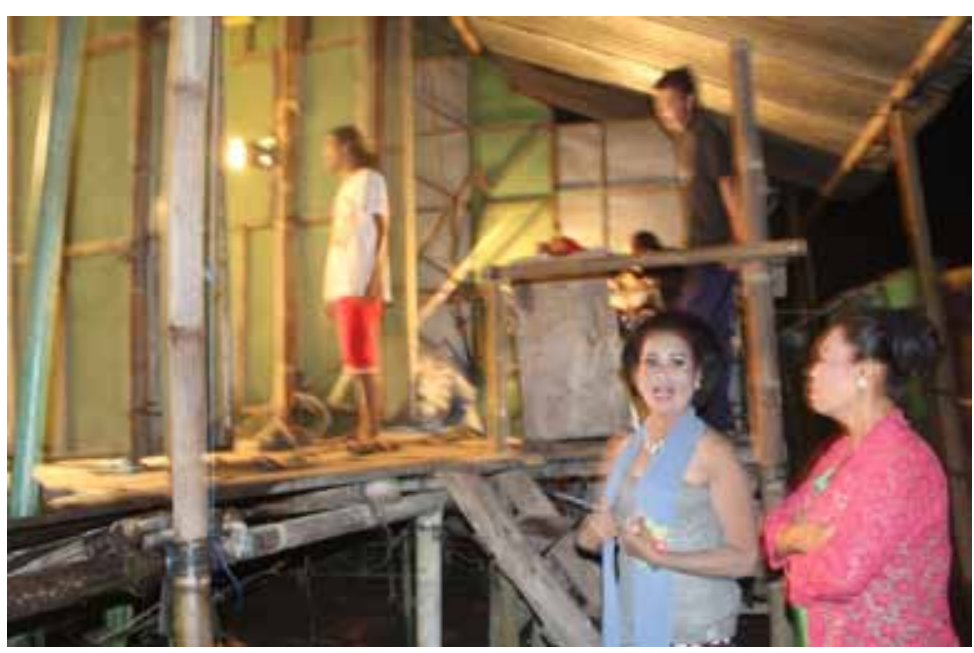

Back Stage 


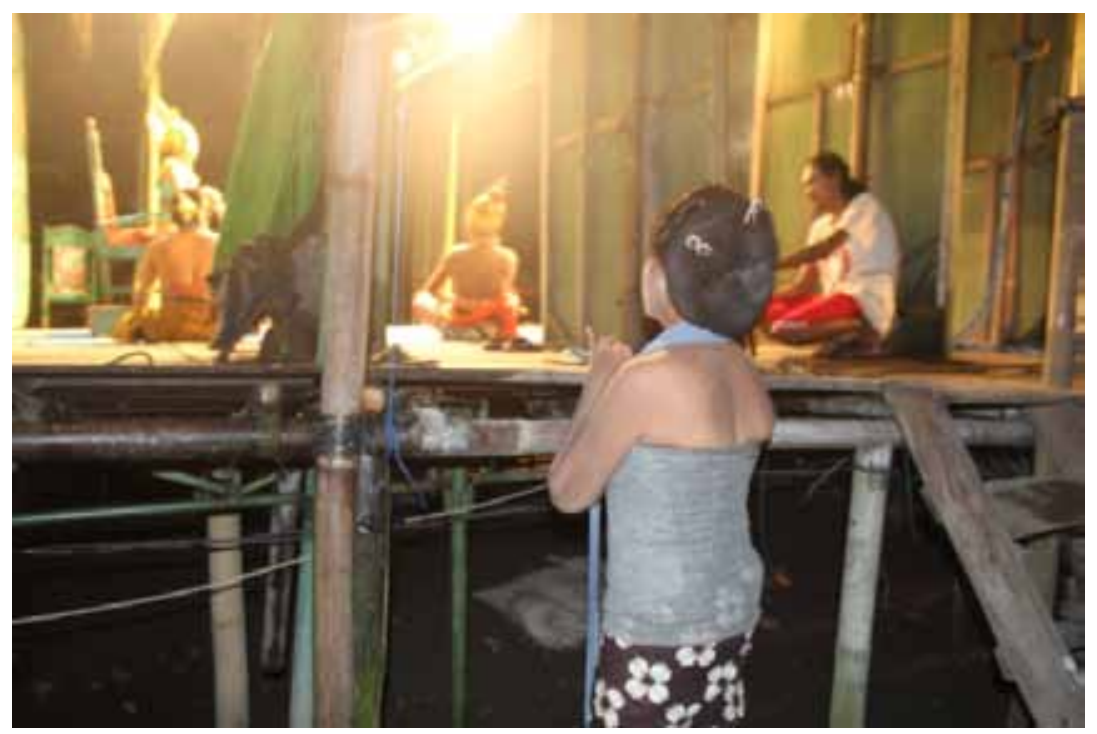

Back Stage

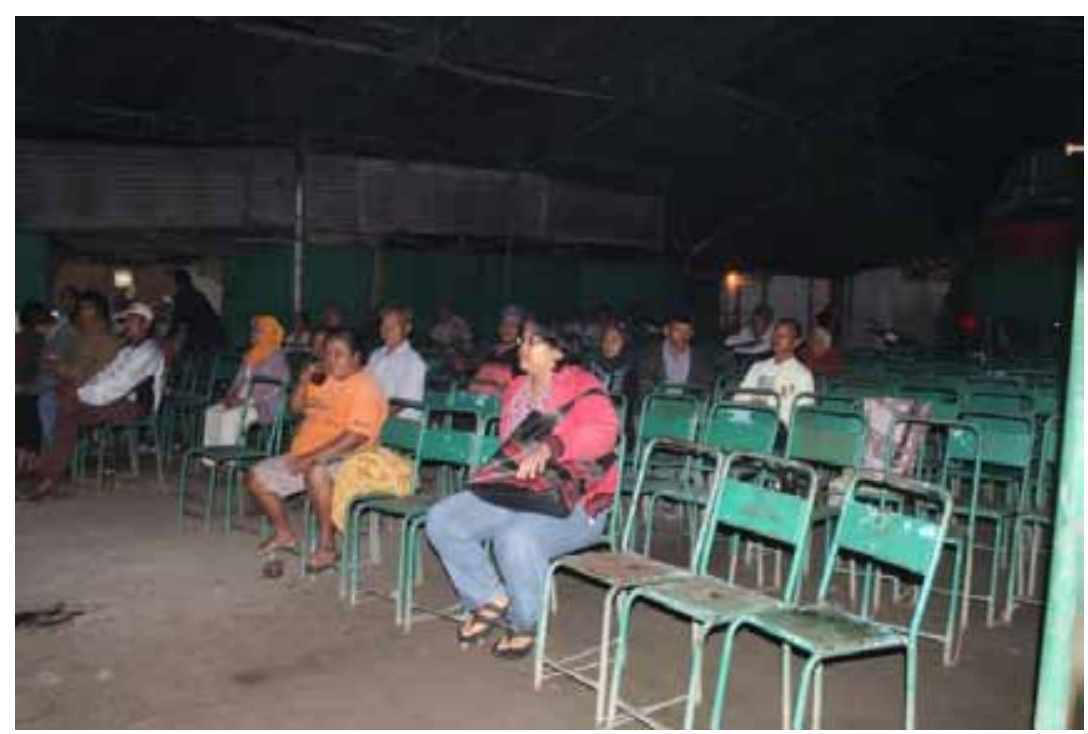

The Audiences

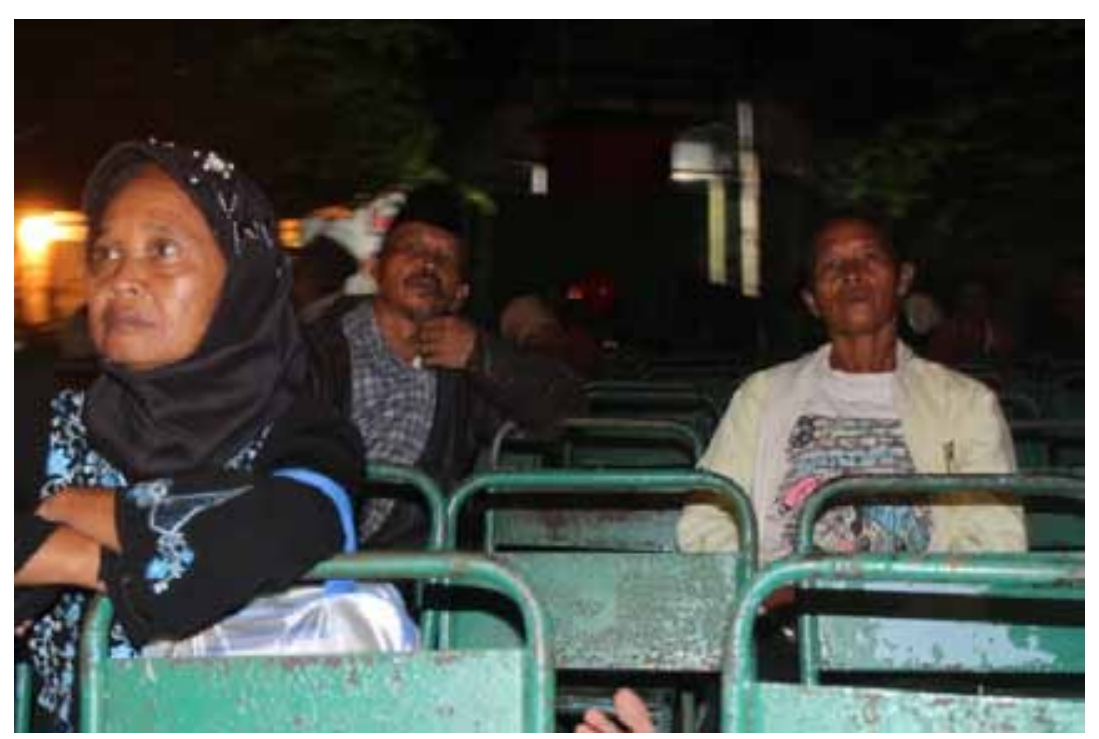

The Audiences 


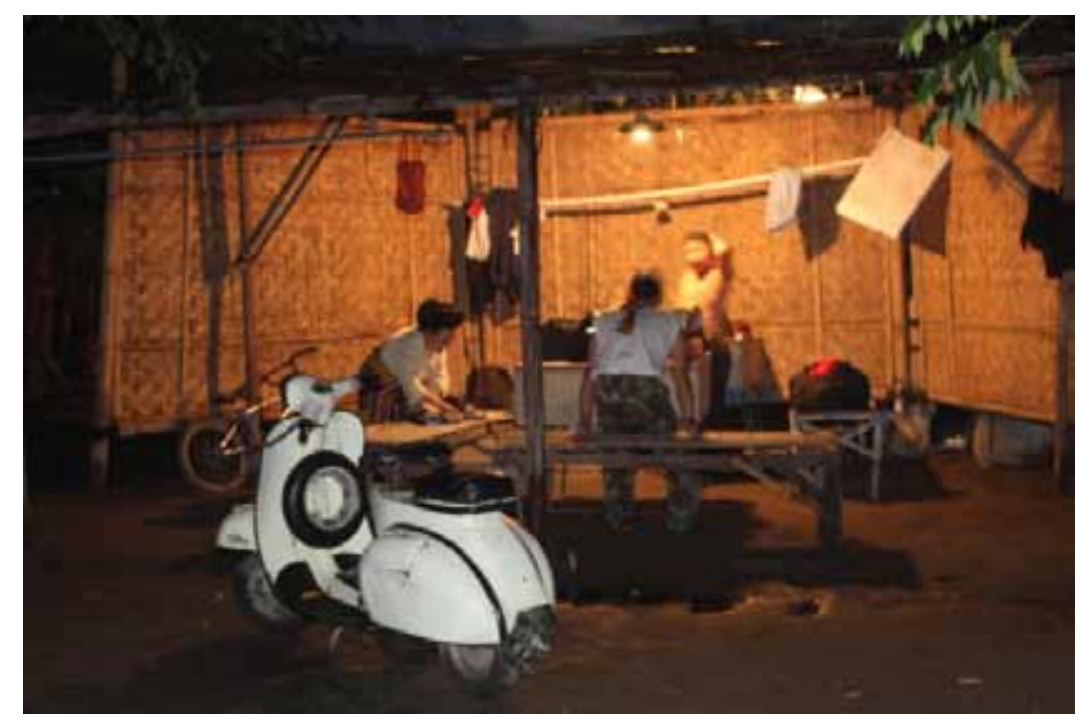

Tobong

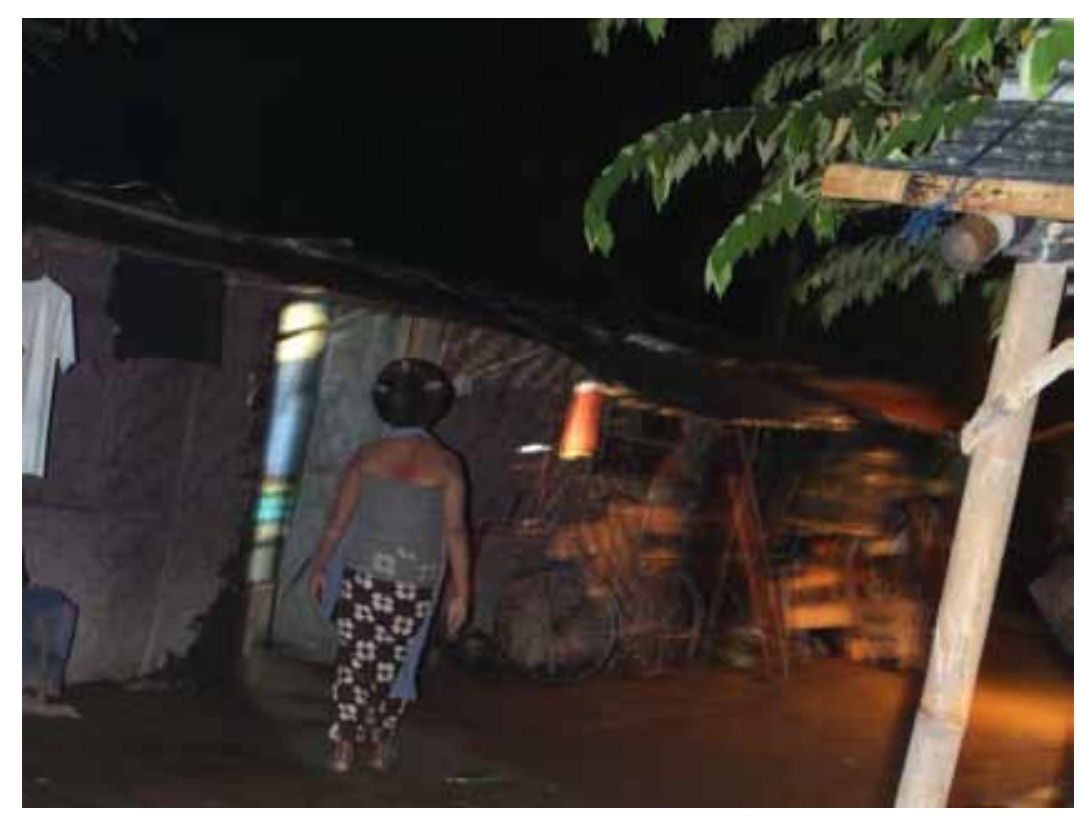

Tobong 